\title{
PARECERES
}

\section{CONCESSIONÁRIA DE ENERGIA ELÉTRICA - POSTES - TAXA MUNICIPAL}

\section{PARECER}

I

Companhia de Eletricidade Nova Friburgo consulta sobre a eventual aplicabilidade da Lei Municipal n. 2.933, de 2 de outubro de 1997, que instituiu taxa de licença para ocupação do solo urbano e rural. A referida lei indica, como fato gerador, "o exercício regular, pelo Poder Público municipal, de autorização, vigilância e fiscalização, visando a disciplinar a ocupação de vias e logradouros públicos para a prática de qualquer atividade onde for permitida, conforme previsto na lei n. 2.249 , de 8 de dezembro de 1988 ".

O parágrafo único do preceito em causa inclui, como atividades abrangidas pela taxa de licença entre outras, "postes de iluminação pública".

Como contribuinte da taxa caracteriza-se, na forma do art. 4\%, "o proprietário ou titular do domínio útil ou o possuidor, a qualquer título, do imóvel alcançado pelo serviço, edificado ou não, que constitua unidade autônoma, independentemente de sua destinaçāo".

A lei produzirá efeitos a partir de 12 de janeiro de 1998 (art. 10).

A consulente é concessionária do serviço federal de energia elétrica em área do Município de Nova Friburgo, e, no desempenho da concessão, mantém, há longo tempo, instalaçōes de linhas aéreas com apoio em numerosos postes colocados, com anuência e conhecimento do Município, em vias públicas, estimados em 15.200 postes urbanos e 3.700 postes rurais.

A instalação dos postes e o referido custo são contabilizados no ativo remunerável da empresa, vinculado ao serviço público federal concedido e, por via de consequiência, integram o patrimônio sujeito à cláusula de reversibilidade à Uniāo, como poder concedente do serviço de distribuiçāo de energia elétrica. São, em suma, bens públicos virtuais da União, essenciais à continuidade do serviço público.

A ambiguiidade da referida lei - mais ainda pela remissão feita à Lei n. 2.249 , de 8 de dezembro de 1988 (Lei do Uso do Solo), que nada dispōe sobre instalaçōes de energia elétrica - motiva a consulta no tocante à eventualidade de que se pretenda cobrar à taxa em apreço, a título de exercício do poder de polícia, quanto aos postes integrantes do serviço.

II

A apreciação do mérito da consulta torna necessário caracterizar, adequadamente, a correlação entre os direitos inerentes à concessão e a utilização, pelo concessionário, de bens públicos municipais indispensáveis à prestação do serviço público federal, concedido.

A Constituição Federal de 1988 - tal como as anteriores - inclui na competência da Uniāo “explorar, diretamente, ou mediante autorizaçāo, concessāo ou permissāo, os serviços e instalaçōes de energia elétrica" (art. $21, \mathrm{n}$. XII, alínea $b$ ) e reserva à competência privativa da União legislar sobre "águas e energia" (art. 22, n. IV).

A legislação federal específica na matéria, faculta aos concessionários, para execuçāo dos trabalhos pertinentes à exploração

\begin{tabular}{lll}
\hline R. Dir. Adm., & Rio de Janeiro, 211:351-362, & jan./mar. 1998 \\
\hline
\end{tabular} 
"utilizar os terrenos de domínio público e estabelecer as servidões nos mesmos e através de estradas, caminhos e vias públicas, com sujeição aos regulamentos administrativos" bem como

"estabelecer as servidões permanentes ou temporárias exigidas para o transporte em distribuição da energia elétrica"

(Código de Águas - Decreto n. 24.643, de 10 de julho de 1934, art. 151, alíneas $a$ e $c$ ).

Regulando o uso necessário de bens de domínio público para os fins de concessão, prevê o correspondente regulamento que a autorização legal vigorará a prazo indeterminado

"e sem ônus para os concessionários de serviços públicos de energia elétrica" (art. $2^{\circ}$ do Decreto n. 84.398, de 16 de janeiro de 1980 , na redação aprovada pelo Decreto $n$. 86.859 , de 19 de janeiro de 1982).

Ratificando a gratuidade do uso de vias públicas para a instalaçāo de serviços de energia elétrica, o $\$ 3^{2}$ do art. 155 da vigente Constituição, prescreve de modo explícito que

“a exceção dos impostos de que tratam o inciso II do caput deste artigo e o art. 153, $\mathrm{n}$. I e II, nenhum outro tributo poderá incidir sobre operaçōes relativas a energia elétrica" (redação dada pela Emenda Constitucional $\mathbf{n}$. 3, de 17-3-1993).

\section{III}

Defluem, claramente, das indicadas disposiçōes constitucionais, legais e regulamentares, que regem o sistema de energia elétrica, os seguintes princípios essenciais:

a) à Uniāo - e, por via delegada, aos concessionários - é assegurado o direito à utilização de bem de domínio público (como são as vias públicas) para a instalação de postes como partes integrantes do sistema de distribuição de energia elétrica;

b) a autorização municipal - expressa ou tácita - não se faz necessária para cada poste ou instalaçāo específica, mas decorre da própria essencialidade e continuidade do serviço destinado ao atendimento dos usuários;

c) as instalações em causa, embora devam atender aos regulamentos administrativos, de modo a não impedir ou perturbar o uso comum, pela população, das vias públicas, não podem ter sua eficácia obstada ou onerada por ato normativo municipal;

d) o uso assegurado aos concessionários durante a concessão, a par da vigência a prazo indeterminado, tem preservada sua gratuidade, não podendo importar qualquer ônus para o prestador do serviço público concedido, nem, obviamente, para os consumidores sobre os quais recairia, pela via das tarifas, o custo final do serviço;

e) de modo especial, por força do princípio constitucional (art. 155, $\$ 3^{\circ}$ da Constituiçāo) nenhuma taxa (como tributo, que é) poderá incidir sobre quaisquer operaçōes de energia elétrica, a se realizarem, no caso, rendo como veículo necessário a rede distribuidora instalada sobre postes na via pública.

\section{IV}

Em caso análogo, a Municipalidade de Regente Feijó foi autorizada, em Lei n. 1.695, de 24 de novembro de 1993, a estabelecer preço público relativamente " ao espaço ocupado pelo sistema de posteamento da rede energética e de iluminação pública, de propriedade da Caiuá Serviços de Eletricidade S.A."

Interposto mandado de segurança preventivo pela concessionária, para que a autoridade municipal se abstivesse da cobrança do preço público, a pretensão mandamental foi acolhida em sentença monocrática, confirmada em grau de recurso ex-officio pelo Primeiro Tribunal de Alçada Civil do Estado de S. Paulo, sob o fundamento básico de que

"é inconstitucional a legislação que estabeleça imposto sobre energia elétrica, ainda que dissimulado de preço público de locaçāo pelo uso do espaço destinado aos postes de fornecimento da concessionária" (acórdāo de 18 de abril de 1996).

$\mathrm{E}$, diante de projeto de lei equivalente que pretendia instituir preço público pela utilização do sol em vias e logradouros públicos no Município de Presidente Prudente, a Consultoria Jurídica do Ministério de Minas e Ener- 
gia repeliu, igualmente, a pretensão por sua invalidade perante os princípios inscritos na Constituição e no Código de Águas (Parecer CONJUR/MME n. 08/94, de 10 de maio de 1994).

A consulta se traduz, objetivamente, em três quesitos essenciais, a saber:

Primeiro - É possível e legítimo o exercício regular de poder de polícia municipal sobre a execução do serviço público federal de energia elétrica e sobre as respectivas instalações, mesmo visando a disciplinar a ocupação de vias e logradouros públicos?

Segundo - É válida a legislação federal que permite ao concessário se utilizar de termos do domínio público e de vias públicas municipais, com sujeição as regulamentos administrativos, mas sem qualquer ônus?

Terceiro - $\mathrm{O}$ artigo $155, \S 3^{\circ} \mathrm{da}$ Constituição afastaria a incidência da taxa?

$O$ atendimento aos três itens recomenda que se destaquem pressupostos que devem qualificar a resposta conjunta às indagaçōes.

A Constituição atribui, privativamente, à Uniāo a prestação do serviço público de energia elétrica que tem como destinatários finais os usuários públicos ou privados.

Exercendo-a diretamente ou delegando-as aos concessionários é, em suma, o poder público federal o agente ativo do serviço essencial à comunidade.

Decorre deste dever precípuo da União a faculdade do uso dos bens de domínio público nas três esferas federativas como, de igual modo, a imunidade tributária de que se reveste o serviço público federal, direto ou concedido.

A utilização do solo para a instalação de postes (Como será igualmente, na hipótese de instalaçōes subterrâneas) é direito legítimo do executor do serviço, quer se trate de órgão estatal, quer se cuide de pessoa jurídica investida do munus público de prestar o serviço, na qualidade de concessionária.

As posturas ou regulamentos administrativos tão-somente poderão especificar requisitos para o procedimento por esta forma garantido ao órgão prestador do serviço na medida em que, sem impedir ou dificultar-lhe substancialmente a atividade precípua, estabeleçam condiçōes complementares de uso, em benefício do interesse da comunidade.

De qualquer modo, é vedado ao Município, a qualquer título, fazer incidir tributo, preço público ou qualquer outro ônus em razão do acesso do prestador do serviço de energia elétrica a logradouros ou vias públicas de seu domínio.

No caso de consulta - ao que e esclarece - os postes existentes integram o patrimônio do próprio concessionário e deles se vale a Municipalidade como ponto de apoio para instalar os seus próprios serviços de iluminação pública, sem que se altere a propriedade do concessionário.

Ainda, porém, na hipótese inversa, em que a concessionária fosse autorizada a se valer de postes de iluminação pública de domínio municipal, ainda assim o correspondente uso estaria protegido pelo princípio da gratuidade de acesso aos bens de domínio público.

Em suma, a taxa de licença prevista na mencionada lei municipal somente poderá incidir sobre particulares que, mediante ocupação de vias ou logradouros públicos, pratiquem atividade contemplada na anterior Lei de Uso do Solo, a que se reporta a nova legislação advinda.

É como nos parece, em razāo da consulta formulada.

Em 10 de dezembro de 1997

CAIO TÁCITO 